\title{
Correlation Studies in Gladiolus (Gladiolus hybridus Hort.) Genotypes
}

\section{Sripada Swetha ${ }^{1}$, Balaji S. Kulkarni ${ }^{2}$, Mukund Shiragur ${ }^{3}$, M. S. Kulkarni ${ }^{4}$, Mahantesha B. N. Naik ${ }^{5}$, Ravindra Mulge ${ }^{6}$ and Laxminarayan Hegde ${ }^{7}$}

\author{
${ }^{1}$ Kittur Rani Channamma College of Horticulture, Arabhavi, India \\ ${ }^{2}$ Department of Floriculture \& Landscape Architecture, University of Horticultural Sciences, \\ Bagalkot, India \\ ${ }^{3}$ Department of Floriculture \& Landscape Architecture, KRC College of Horticulture, \\ Arabhavi, India \\ ${ }^{4}$ University of Horticultural Sciences, Bagalkot, India \\ ${ }^{5}$ Department of Biotechnology \& Crop Improvement, KRC College of Horticulture, Arabhavi \\ ${ }^{6}$ College of Horticulture, Halladkeri Farm, Bidar, India \\ ${ }^{7}$ College of Horticulture Engineering and Food technology, Devihosur, India
}

*Corresponding author

\section{A B S T R A C T}

\begin{tabular}{|l|}
\hline Keyw or d s \\
Gladiolus, \\
Genotypic \\
correlation, \\
Phenotypic \\
correlation, Spike \\
\hline Article Info \\
\hline Accepted: \\
08 January 2020 \\
Available Online: \\
10 February 2020 \\
\hline \hline
\end{tabular}

\section{Keywords}

Gladiolus,

Genotypic

correlation,

Phenotypic

correlation, Spike

Article Info

Accepted:

8 January 2020

Available Online:

\section{Introduction}

Gladiolus (Gladiolus hybridus Hort.) is an important bulbous ornamental prized for its beauty of spikes as well as longer vase-life and said to be "Queen of bulbous flower
A study on the association of various morphological traits through correlation analysis in gladiolus (Gladiolus hybridus Hort.) showed that Number of spikes per plant had a significant and positive correlation with number of leaves, number of shoots and number of daughter corms per plant in genotypic level. Spike length exhibited positive and significant association with rachis length, number of florets vase life and number of cormels. Number of florets exerted a significant positive correlation with vase life at genotypic and phenotypic level. Hence, these characters may be considered as selection indices in gladiolus breeding programme. 
There are many excellent cultivars of gladiolus with magnificent inflorescence, in exhaustive range of colours, different shades, varying number of florets, size, wide range of keeping quality and adaptability to different seasons. It is relatively easy to grow and is ideal for bedding and exhibition purposes. The spikes are used in vase arrangements, in bouquets and for indoor decorations. Popularity of this crop as a cut spike is increasing day by day because of its long keeping quality and exhaustive range of colours of the spikes.

In any crop improvement programme, it becomes necessary to have simultaneous progress of more than one character, especially in the case of complex character like yield, which is influenced by many other traits. This is due to the physiological and linkage relationship of genes governing various characters. Hence, knowledge of correlations between different economical traits is of importance in selection programmes.

\section{Materials and Methods}

The present investigation was carried out at the Department of Floriculture and Landscape Architecture, Kittur Rani Channamma College of Horticulture (University of Horticultural Sciences, Bagalkot), Arabhavi, Gokak taluk, Belagavi district of Karnataka during the period of 2015 to 2017. Forty gladiolus genotypes collected from diverse source were used in the study presented in Table 1. The experiment was laid out in randomized block design (RBD) with two replications.

Genotypic $\left(r_{\mathrm{g}}\right)$ and phenotypic $\left(\mathrm{r}_{\mathrm{p}}\right)$ correlation coefficients were estimated as suggested by Al-Jibourie et al., (1958)

Genotypic correlation $=r_{x y}(g)=\frac{\operatorname{CoV} x y(G)}{\sqrt{\operatorname{Vx}(G) \times V y(G)}}$
Phenotypic correlation $=r_{x y}(p)=\frac{\operatorname{CoVxy}(P)}{\sqrt{\operatorname{Vx}(P) \times V y(P)}}$

Where,

CoVxy $(\mathrm{G})=$ Genotypic covariance between $\mathrm{x}$ and $\mathrm{y}$

CoVxy $(\mathrm{P})=$ Phenotypic covariance between $\mathrm{x}$ and $\mathrm{y}$

Vx $(G)=$ Genotypic variance of character $x$

$\mathrm{Vx}(\mathrm{P})=$ Phenotypic variance of character $\mathrm{x}$

$\mathrm{Vy}(\mathrm{G})=$ Genotypic variance of character $\mathrm{y}$

Vy $(P)=$ Phenotypic variance of character $y$

Test of significance of correlation was tested by comparing the ' $r$ ' value with obtained value.

\section{Results and Discussion}

The analysis of phenotypic and genotypic correlation of yield and yield components were worked out for the twelve important quantitative characters using mean data generated from 40 genotypes raised during two continuous seasons from 2015-17, and the pooled analysis of both seasons presented in Table 2 and 3.

Changes in yield must be accompanied by changes in one or more of its components. In the present investigation, it was observed that genotypic correlation coefficients were found to be higher than corresponding phenotypic correlation coefficient for all the characters indicating little influence of environment and the presence of a strong inherent association between various characters. In most of the cases genotypic and phenotypic correlation coefficients were similar in direction (Mishra et al., 2014, Choudhary et al., 2011 in gladiolus).

Number of spikes per plant had significant and positive correlation with number of leaves, number of shoots and number of daughter corms per plant in genotypic level which indicated that selection based on these characters would increase spike yield. Negative and significant correlation was 
expressed for yield trait with days to spike emergence, leaf area per plant and plant height at both genotypic and phenotypic levels. The results are in accordance with Mishra et al., (2014), who reported that number of spikes per plant had significant and positive correlation with number of sprouts and number of corms per plant in gladiolus. Aido et al., (2014) in gladiolus also quoted that the magnitude of correlation with flower yield was highest in number of leaves at spike initiation stage. Geeta (2013) and Sahana (2010) also reported that number of spikes per plant had significant positive correlation with number of daughter corms and negative correlation with plant height, leaf area and days to spike emergence in gladiolus.

Plant height showed significant and positive correlation with weight of corm before planting, leaf area per plant, spike length, rachis length, number of cormels and vase life. This indicated that the plant height is an important trait for quality spike production, selection of genotypes based on these characters is important. Similar results were obtained by Ramzan et al., (2016), Katwate et al., (2002), Maitra and Sathya (2004) and Choudhary et al., (2011) in gladiolus.

Selection of taller plants and large spikes will therefore simultaneously improve post harvest life of the spike, which is one of the most important quality characters of gladiolus flower. Katwate et al., (2002) found that rachis length exhibited significant positive correlation with plant height and number of florets per spike indicating that the increased plant height will result in increased rachis length thereby improving the value of genotype. It was significant and negatively associated with number of shoots, number of leaves and number of spikes per plant. This is in conformity with the results of Geetha et al., (2014) and Sahana et al., (2010) in gladiolus. So selection of genotypes which have higher plant height will increase the value of a genotype in terms of spike quality. Number of shoots had positive and significant correlation with number of leaves, number of daughter corms per plant while, leaf area and days to spike emergence showed significantly negative correlation with number of shoots which indicated that direct selection of genotypes based on these characters can be done to increase the number of shoots. Similar results were reported by Vetry et al., (2017) in gladiolus. A non significant negative correlation was observed by number of cormels per plant with number of shoots. This consequence is in comparison with the results reported by Mishra et al., (2014) in gladiolus.

Number of leaves expressed significant positive correlation with number of spikes, number of daughter corms per plant and significantly negatively associated with leaf area per plant and days to spike emergence. The results are in accordance with Aido et al., (2014) and Nimbalkar et al., (2007) in gladiolus.

A significant positive correlation was exerted by spike length with weight of corm before planting, plant height, leaf area, rachis length, vase life, number of florets per spike and number of cormels. Similar findings were made by Maitra and Sathya (2004) and Choudhary et al., (2011) in gladiolus. It shows that spike length, which is an important attribute of cut flower quality, can be increased with increase in any one of these characters, specially the height of the plant, number of florets per spike and corm weight. Similarly, the market value and marketability of gladiolus spikes depends upon the number of florets per spike, floret size and number of florets open at a time and as these characters had positive correlation with spike length, so a direct selection from germplasm lines may be effective for the improvement of this crop. 
Table.1 Details of gladiolus genotypes used in the experiment

\begin{tabular}{|c|c|c|c|}
\hline S. No & Genotype & Origin & Source \\
\hline 1. & Summer Sunshine & Holland & Jammu \& Kashmir \\
\hline 2. & Delhi Local & India & Jammu \& Kashmir \\
\hline 3. & Green Bay & USA & Jammu \& Kashmir \\
\hline 4. & Copper King & USA & Jammu \& Kashmir \\
\hline 5. & Dhanvantari & - & IARI, New Delhi \\
\hline 6. & JesterYellow & Holland & Jammu \& Kashmir \\
\hline 7. & LocalYellow & India & Bengaluru \\
\hline 8. & Arka Amar & IIHR & IIHR, Banglore \\
\hline 9. & Arka Naveen & IIHR & IIHR, Banglore \\
\hline 10. & Arka Arti & IIHR & IIHR, Banglore \\
\hline 11. & Darshan & India & IIHR, Banglore \\
\hline 12. & Jyostna & - & IARI, New Delhi \\
\hline 13. & Suchitra & - & IARI, New Delhi \\
\hline 14. & Magma & - & Navsari, Gujrat \\
\hline 15. & Urmil & - & IARI, New Delhi \\
\hline 16. & White Prosperity & USA & Jammu \& Kashmir \\
\hline 17. & Pusa Kiran & IARI & IARI, New Delhi \\
\hline 18. & Sindur & - & IIHR, Banglore \\
\hline 19. & Arka Thilak & IIHR & IIHR, Banglore \\
\hline 20. & Punjab Dawn & India & Navsari, Gujrat \\
\hline 21. & African star & - & IARI, New Delhi \\
\hline 22. & Local pink & - & Bengaluru \\
\hline 23. & Pusa Vidushi & IARI & IARI, New Delhi \\
\hline 24. & Legent & - & IARI, New Delhi \\
\hline 25. & Chandini & - & IARI, New Delhi \\
\hline 26. & Mohini & NBRI & IARI, New Delhi \\
\hline 27. & Hunting Song & - & IARI, New Delhi \\
\hline 28. & Golddust & - & IARI, New Delhi \\
\hline 29. & Surya Kiran & - & IARI, New Delhi \\
\hline 30. & Sunayana & - & Navsari, Gujrat \\
\hline 31. & Gunjan & - & PAU, Ludhiana \\
\hline 32. & Novalux & - & PAU, Ludhiana \\
\hline 33. & Punjab glance & India & IARI, New Delhi \\
\hline 34. & Anjali & IARI & Navsari, Gujrat \\
\hline 35. & Shagun & - & IARI, New Delhi \\
\hline 36. & Priscilla & - & IIHR, Banglore \\
\hline 37. & Arka Sagar & IIHR & IIHR, Banglore \\
\hline 38. & Arka Kesar & IIHR & IIHR, Banglore \\
\hline 39. & Arka Gold & IIHR & Jammu \& Kashmir \\
\hline 40. & Candyman & USA & Jammu \& Kashmir \\
\hline
\end{tabular}


Table.2 Genotypic correlation coefficient for growth, flowering, yield and quality parameters in gladiolus genotypes

\begin{tabular}{|c|c|c|c|c|c|c|c|c|c|c|c|c|c|}
\hline & WCP & PH & NS & $\mathbf{N L}$ & $\mathbf{L A}$ & DSE & SL & $\mathbf{R L}$ & $\mathbf{N F}$ & VL & NDC & $\mathbf{N C r}$ & NSp \\
\hline WCP & 1.000 & $0.499 * *$ & -0.190 & $-0.300 * *$ & $0.574 * *$ & -0.025 & $0.664 * *$ & $0.629 * *$ & $0.522 * *$ & $0.587^{* *}$ & -0.200 & $0.485^{* *}$ & -0.091 \\
\hline PH & & 1.000 & $\begin{array}{c}- \\
0.399 * *\end{array}$ & $-0.283^{*}$ & $0.807 * *$ & 0.062 & $0.640 * *$ & $0.388 * *$ & 0.151 & $0.219 *$ & 0.002 & $0.365 * *$ & $-0.272 *$ \\
\hline NS & & & 1.000 & $0.833 * *$ & $-0.492 * *$ & $-0.326^{* *}$ & -0.052 & 0.144 & 0.205 & 0.187 & $0.260^{*}$ & -0.212 & $0.774 * *$ \\
\hline NL & & & & 1.000 & $-0.464 * *$ & $-0.434^{* *}$ & -0.009 & 0.151 & 0.189 & 0.168 & $0.388 * *$ & -0.142 & $0.942 * *$ \\
\hline LA & & & & & 1.000 & 0.135 & $0.762 * *$ & $0.450 * *$ & $0.359 * *$ & $0.410 * *$ & 0.023 & $0.404^{* *}$ & $-0.398 * *$ \\
\hline DSE & & & & & & 1.000 & -0.017 & -0.029 & -0.134 & -0.126 & -0.149 & $0.334 * *$ & $-0.491 * *$ \\
\hline SL & & & & & & & 1.0000 & $0.830 * *$ & $0.672 * *$ & $0.723 * *$ & 0.157 & $0.426^{* *}$ & 0.027 \\
\hline $\mathbf{R L}$ & & & & & & & & 1.0000 & $0.793 * *$ & $0.819 * *$ & 0.045 & $0.508 * *$ & 0.190 \\
\hline $\mathbf{N F}$ & & & & & & & & & 1.0000 & $0.972 * *$ & -0.067 & $0.264 *$ & 0.190 \\
\hline VL & & & & & & & & & & 1.000 & -0.044 & $0.267 *$ & 0.192 \\
\hline NDC & & & & & & & & & & & 1.000 & 0.182 & $0.228 *$ \\
\hline $\mathrm{NCr}$ & & & & & & & & & & & & 1.000 & -0.214 \\
\hline NSp & & & & & & & & & & & & & 1.000 \\
\hline
\end{tabular}

Critical $r_{g}$ value $=0.219$ at 5 per cent and 0.286 at 1 per cent

$*$ and $* *$ indicate significant at 5 and 1 per cent probability level, respectively

WCP - Weight of corm before planting $(\mathrm{g})$

$\mathrm{PH}$ - Plant height (cm)

NS - Number of shoots

NL - Number of leaves

LA - Leaf area $\left(\mathrm{cm}^{2}\right)$
DSE - Days to spike emergence

SL - Spike length $(\mathrm{cm})$

RL - Rachis length (cm)

NF - Number of florets

VL - Vase life (days)
NDC - Number of daughter corms per plant

$\mathrm{NCr}$ - Number of cormels per plant

NSp - Number of spikes per plant 
Table.3 Phenotypic correlation coefficient for growth, flowering, yield and quality parameters in gladiolus genotypes

\begin{tabular}{|c|c|c|c|c|c|c|c|c|c|c|c|c|c|}
\hline & WCP & PH & NS & NL & $\mathbf{L A}$ & DSE & SL & $\mathbf{R L}$ & $\mathbf{N F}$ & VL & NDC & $\mathrm{NCr}$ & NSp \\
\hline WCP & 1.000 & $0.419 * *$ & -0.109 & -0.122 & $0.447 * *$ & -0.043 & $0.539 * *$ & $0.531 * *$ & $0.393 * *$ & $0.476^{* *}$ & -0.115 & $0.393 * *$ & -0.021 \\
\hline PH & & 1.000 & $-0.259 *$ & -0.169 & $0.775 * *$ & 0.062 & $0.551 * *$ & $0.316^{* * *}$ & 0.092 & 0.165 & -0.008 & $0.324 * *$ & $-0.239 *$ \\
\hline NS & & & 1.000 & $0.805^{* *}$ & $-0.303^{* *}$ & -0.125 & -0.013 & 0.108 & 0.144 & 0.138 & 0.189 & -0.198 & $0.688 * *$ \\
\hline NL & & & & 1.000 & $-0.301 * *$ & -0.192 & 0.025 & 0.122 & 0.135 & 0.133 & $0.279 *$ & -0.135 & $0.791 * *$ \\
\hline $\mathbf{L A}$ & & & & & 1.000 & 0.096 & $0.648 * *$ & $0.374 * *$ & $0.241 *$ & $0.301 * *$ & 0.027 & $0.359 * *$ & $-0.307 * *$ \\
\hline DSE & & & & & & 1.000 & 0.010 & -0.013 & -0.078 & -0.088 & -0.141 & 0.140 & $-0.312 * *$ \\
\hline SL & & & & & & & 1.000 & $0.828 * *$ & $0.659 * *$ & $0.704 * *$ & 0.148 & $0.336 * *$ & 0.012 \\
\hline $\mathbf{R L}$ & & & & & & & & 1.000 & $0.773 * *$ & $0.797 * *$ & 0.082 & $0.399 * *$ & 0.142 \\
\hline NF & & & & & & & & & 1.000 & $0.947 * *$ & 0.004 & 0.174 & 0.149 \\
\hline VL & & & & & & & & & & 1.000 & 0.015 & $0.215^{*}$ & 0.156 \\
\hline NDC & & & & & & & & & & & 1.000 & 0.122 & 0.186 \\
\hline $\mathrm{NCr}$ & & & & & & & & & & & & 1.000 & -0.206 \\
\hline NSp & & & & & & & & & & & & & 1.000 \\
\hline
\end{tabular}

Critical $r_{g}$ value $=0.219$ at 5 per cent and 0.286 at 1 per cent

$*$ and $* *$ indicate significant at 5 and 1 per cent probability level, respectively

WCP - Weight of corm before planting $(\mathrm{g})$

$\mathrm{PH}$ - Plant height $(\mathrm{cm})$

NS - Number of shoots

NL - Number of leaves

LA - Leaf area $\left(\mathrm{cm}^{2}\right)$
DSE - Days to spike emergence

SL - Spike length (cm)

RL - Rachis length (cm)

NF - Number of florets

VL - Vase life (days)
NDC - Number of daughter corms per plant

$\mathrm{NCr}$ - Number of cormels per plant

$\mathrm{NSp}$ - Number of spikes per plant 
Rachis length was significantly and positively correlated with vase life, number of florets per spike and number of cormels per plant. This result is in accordance with the findings of Raj et al., (1998), Choudhary et al., (2011), Anju and Ranvir (2012) and Anwesha and Ratha (2015) in gladiolus.

On the basis of findings of the present experiment the following conclusion may be drawn, most of the characters have higher genotypic correlation coefficent than phenotypic correlation coefficent. For improvement of spike yield through selection, much emphasis should be given on the characters like number of leaves, number of shoots and number of daughter corms per plant.

\section{References}

Aido, T., Genetic divergence studies in gladiolus (Gladiolus grandiflorus L.) 2014, Dr. Y.S.R. Horticultural University. M.Sc. Thesis.

Al-Jibourie, H. A., Miller, P. A. and Robinson, H. F., 1958, Genetic and environmental variance in an upland cotton cross on interspecific origin. Agron. J., 50: 633-637.

Anju, P. and Ranvir, S., 2012, Correlation and path coefficient analysis in gladiolus. Ann. Hort., 5 (1): 103-107.

Anwesha, Ratha, and Das, J. N., 2015, Genetic variability in gladiolus. Thesis. Orissa University of Agriculture and Technology.

Choudhary, M., Moond, S. K. and Kumari, A., 2011, Correlation studies in gladiolus. Res. Plant Biol., 1(4): 68-72.

Geeta, 2013, Morphological and molecular characterization in gladiolus (Gladiolus hybridus Hort.) varieties. M.Sc. Thesis, University of Horticultural Sciences, Bagalkot.

Katwate, S. M., Warade, S. D., Nimbalkar, C. A. and Patil, M. T., 2002, Correlation and path analysis studies in gladiolus. J. Maharashtra agric. Univ., 27(1): 40-43.

Maitra, S. and Satya, P., 2004, studies on genetic parameters of some off-season planted gladiolus genotypes in humid subHimalayan region. J. Ornamental Horti., 7(3-4): 57-62.

Mishra, P., Singh, A. K. and Singh, O. P., 2014, Genetic variability, heritability, genetic advance, correlation coefficient and path analysis in gladiolus. IOSR J. Agric. Vet. Sci., 7 (7): 23-26.

Nimbalkar C. A., Katawate, S. M., Singh, B. R., Kakade, D. S. and Gurav, S. B., 2007, Selection strategy for improvement in economic traits of gladiolus. J. Ornamental Horti., 10(1): 9-14.

Raj, R. L. D., Saini, M. H. C. and Dohare, S. R., 1998, Correlation and path-coefficient studies in gladiolus over different environments. J. Ornamental Horti., 1(1): 26-31.

Ramzan, A, Nawab, N. N., Ahad, A., Hafiz, A. I., Tariq, S. M. and Ikram, S., 2016, Genetic variability, correlation studies and path coefficient analysis in Gladiolus alatus cultivars. Pak. J. Bot., 48(4): 1573-1578.

Sahana, K., 2010, Studies on genetic variability in gladiolus (Gladiolus hybridus Hort.). M. Sc. (Hort.) Thesis, Univ. Agric. Sci., Dharwad.

Verty, P., Prasad, V. M., Collis, J. P. and Nazir, M., 2017, Correlation analysis in gladiolus (Gladiolus grandiflorus L.). Agric. Res. Tech., 10(4): 1-6.

\section{How to cite this article:}

Sripada Swetha, Balaji S. Kulkarni, Mukund Shiragur, M. S. Kulkarni, Mahantesha B. N. Naik, Ravindra Mulge and Laxminarayan Hegde. 2020. Correlation Studies in Gladiolus (Gladiolus hybridus Hort.) Genotypes. Int.J.Curr.Microbiol.App.Sci. 9(02): 525-531.

doi: https://doi.org/10.20546/ijcmas.2020.902.065 